\title{
MODEling SPATIAL AND TEMPORAL DYNAMICS OF MONTANE MEADOWS AND BIODIVERSITY IN THE Greater Yellowstone ECOSYSTEM
}

\author{
DIANE M. DEBINSKI $\downarrow$ DEPARTMENT OF ANIMAL ECOLOGY \\ IOWA STATE UNIVERSITY $\uparrow$ AMES \\ MARK E. JAKUBAUSKAS \\ KANSAS APPLIED REMOTE SENSING (KARS) PROGRAM \\ UNIVERSITY OF KANSAS $\downarrow$ LAWRENCE \\ KELLY KINDSCHER $\uparrow$ KANSAS BIOLOGICAL SURVEY \\ UNIVERSITY OF KANSAS $\uparrow$ LAWRENCE
}

\begin{abstract}
$\uparrow$ ABSTRACT
We used remotely sensed imagery to identify and map montane meadow types (M-types) along a moisture gradient, and to develop spectrally-based spatially-explicit models for predicting species diversity patterns in two regions of the Greater Yellowstone Ecosystem: 1) Grand Teton National Park and Bridger Teton National Forest and 2) the Gallatin National Forest and Yellowstone National Park. We investigated the potential to predict species assemblages associated with these meadow types and we also tested our ability to classify specific subsets of montane meadow types such as wetland and sagebrush communities. We also compared our results to the predictability of communities when our sampling sites were classified by GAP analysis. We classified wetlands into 2 categories that differed by the percentage of obligate wetland plant species. Accuracy of wetland classification based upon remotely sensed data was $70 \%$. We classified 4 sagebrush communities [low sagebrush (Artemesia arbuscula), big sagebrush (Artemesia tridentata ssp. vaseyana), mixed low sagebrush/big sagebrush, and bitterbrush (Purshia tridentata)/big sagebrush].
\end{abstract}

Overall accuracy of our sagebrush community classification based upon remotely sensed data was $65 \%$, and was highest for the mixed big sagebrush/low sagebrush community at $86 \%$. We also investigated the association of plant, bird and butterfly species with each of the meadow types. Because of the rarity of many of the species, our analyses focused on species for which we had minimum standards of data. These standards varied among taxonomic groups, but species only observed infrequently were not included in the analyses. The abundances of 6 of the 11 most abundant bird species were significantly correlated with meadow type as defined by satellite imagery. However, 10 out of 11 bird species showed a significant correlation when both remotely sensed data and landscape variables (e.g., shrub biomass, percent cover of willow or sagebrush, and meadow area) were added to the models. Butterfly species showed even stronger associations with particular meadow types, especially in the Teton region. We used regression tree analyses to separate meadow types by their associated species of butterflies. Fourteen of 67 butterfly species distribution patterns could be used to classify sampling sites into one of five different meadow types with $92 \%$ accuracy in 1997 
and $96 \%$ accuracy in 1998 . From the perspective of global climate change indicators, mesic meadows showed the greatest seasonal and interannual variability in spectral response and highest species diversity of plants. Given the rich biodiversity of mesic montane meadows and their sensitivity to variations in temperature and moisture, they may be important to monitor in the context of environmental change. Finally, we were able to do some additional related studies funded by a grant from the Nature Conservancy's David H. Smith Fellowship program (to Su and Debinski). We compared the scale of mapping of biotic communities in the EPA-funded project with the GAP analysis approaches in Montana and Wyoming. We found that both the 1 ha MMU M-Type map and 100 ha MMU Wyoming GAP map were significantly associated with bird, butterfly and plant community similarity. However, the 2 ha Montana GAP map was not associated with bird and plant community similarity and only discriminated differences in butterfly species composition between one map class and the others. This difference is probably explained by the fact that Montana GAP had a coarser categorical resolution of meadow types which was not sensitive to community variation associated with the hydrology of the meadows.

\section{$\downarrow$ OBJECTIVES OF RESEARCH AND SAMPLING APPROACH:}

Our project was an examination of ecological dynamics in the Greater Yellowstone Ecosystem (GYE), concentrating specifically upon the spatial and temporal dynamics of montane meadow communities. We examined both the abiotic aspects of these communities as well as the biodiversity of plant, bird and butterfly communities. Our long-term goal was to develop predictive species assemblage models based upon landscape level habitat analysis. This involved using intensive, local field sampling to test for relationships between species distribution patterns and remotely sensed data. Our research involved several steps: 1) quantifying the spatial and temporal variability in montane meadow communities; 2) developing a spectrally-based spatially-explicit model for predicting plant and animal species diversity patterns in montane meadows; and 3 ) testing the spectrally-based sp atially-explicit model for predicting plant and animal species diversity patterns in montane meadows.

The species composition and vegetation condition of montane meadow communities are closely linked to environmental conditions, and based on narrowly defined adaptations to gradients of temperature and moisture (Knight, 1994). Short-term changes in environmental conditions are manifested as changes in vegetation condition, while long-term, directional shifts in temperature and moisture regimes drive changes in species composition and diversity (Harte and Shaw, 1995). Under conditions of warmer and dryer climate, the habitat of individual meadow plant and animal species may be reduced or eliminated (Romme and Turner, 1991). If montane meadows are to function as indicators of environmental change, baseline conditions and variability must be documented such that departures from baselines can be used as an indicator of change.

Yellowstone and Grand Teton National Parks, and the surrounding national forests form what has come to be known as the Greater Yellowstone Ecosystem, roughly defined as the Yellowstone Plateau and elevations above $2130 \mathrm{~m}$ in the surrounding region. Nonforest cover types within the ecosystem range from hydric willow and sedge meadows to high-altitude tundra and rock meadows.

We used a time series of satellite multispectral imagery for monitoring the extent, condition, and spatial pattern of montane meadows on a seasonal and interannual time scale. Field sampling was used to collect data on the distribution of plant, bird, and butterfly species. Spectrallybased, spatially-explicit models were developed for six meadow types using a GIS to stratify the study area by topography and geology. We sampled for four years in two regions of the ecosystem: the northern region (hereafter termed the Gallatin study area) included the Gallatin National Forest and northwestern portion of Yellowstone National Park; the southern region (hereafter termed Teton study area) included Grand Teton National Park. These two regions are $192 \mathrm{~km}$ apart, but have very similar plant and animal communities. Twenty-five sample sites were located in the Tetons and thirty sample sites were located in the Gallatins during 1997 and 1998. These were termed the "core sites" and were sampled each of the four years. Birds, butterflies, and plants were surveyed at each of the sites. Details of the sampling methodology and data analysis are noted below.

During the summer of 1999 and 2000, we mounted a field campaign that will allow us to test the predictability of our models within each region. We visited "additional" sites of each meadow type in 
each sampling area for collection of bird, butterfly, and plant data. This field season focused on extensive rather than intensive data collection (i.e., we visited many new sites, but collected data less frequently at each site). In 1999, 40 new sites were added in the Tetons ( 8 of each meadow type) and 34 new sites were added in the Gallatins (5-6 in each meadow type). In 2000, the sampling was limited to birds and butterflies.

\section{$\downarrow \quad$ ACCOMPLISHMENTS AND RESEARCH RESULTS:}

\section{Meadow Map Production}

Computer classification of multitemporal SPOT multispectral satellite imagery was used to produce maps of spectrally distinct meadow classes within the Gallatin and Teton study areas (hereafter termed the "1997" series of meadow maps). The SPOT satellite remote sensing system records reflected light in three spectral bands (green, red, and near-infrared), with a spatial resolution of $20 \mathrm{~m}$. A multitemporal approach, using two seasons of data, has been proven in other research to be superior for land use/land cover mapping. Therefore, a summer and a fall date of SPOT multispectral i magery were selected for each study region. Data for May 25 and September 6, 1994 were used for the Gallatin National Forest; data from June 17 and September 3, 1996 were used for the Teton study area. Selection of dates was a function of orbital revisit dates, cloud cover, and availability.

Data were converted from brightness values to units of radiance $\left(\mathrm{mW} / \mathrm{cm}^{2} / \mathrm{sr} / \mathrm{um}\right)$ and then reflectance. Data were further normalized for differential illumination effects by performing a topographic normalization procedure, using the DEM data re-sampled to $20 \mathrm{~m}$. All satellite imagery were georeferenced to a Universal Transverse Mercator (UTM) coordinate system with a pixel size of $20 \mathrm{~m}$. The three-band multispectral data for the summer and fall dates for each area (Teton and Gallatin) were then combined into a six-band data file for each study area.

An Iterative Self-Organizing Data Analysis (ISODATA) clustering algorithm was applied to each six-band image file to identify spectrally similar pixels. Thirty to fifty initial clusters were specified for the ISODATA clustering, producing a map of spectral classes. Each spectral class was then identified and assigned to an information class representing a vegetation type. Based on spectral similarity, and visual interpretation of the classes with the assistance of aerial photography and knowledge of the study area, the spectral classes were combined to create a five-class map of coniferous forest, water, developed lands, deciduous forest, and non-forested (meadow) vegetation. This five-class map was then recoded to a binary map of meadow/non-meadow, and used to mask the sixband image file, producing a new image file containing data only for meadow areas. ISODATA clustering $w$ as again applied to the masked data to identify spectral differences in the meadow class only, producing a final map of distinct meadow classes. Six non-forested meadow classes, representing a xeric-to-hydric gradient from sedge meadow (M1) to dry grassland with sagebrush (M6) were identified and mapped. FRAGSTATS computer program (McGarigal and Marks 1994) was used to analyze landscape differences in meadow size, distance to next meadow of the same type, and type of adjacent habitat between sampling areas. These landscape-level parameters can have significant effects on species distribution at a particular point in the landscape.

Fieldwork in 1997 and 1998 indicated some inconsistencies between the "1997" series of meadow maps (as described above) and our determinations of probable meadow classes from field observations and data, particularly for M2 meadow classes in Gallatin. We therefore created a new generation of meadow maps for Gallatin (the "1999" series), using a nine-band data set created using the May 25, 1994 data described above and two new scenes acquired in 1998 (July 12, 1998 and August 28, 1998). Georeferencing, conversion to radiance and reflectance, and classification of the nine-band data set followed procedures described above, in a progressive classify-mask-reclassifymask procedure to identify the six classes of meadows defined above. The result was a set of meadow maps more in congruence with actual meadow type than the 1997 series of maps, yet does not depart substantially from the 1997 maps.

\section{Selection of Sampling Sites}

Because class polygons smaller than 1 ha would be difficult to locate with confidence in the field, the final vegetation maps for field use were generalized to a minimum mapping unit of 25 pixels, or 1 ha. Final maps were plotted on translucent paper at a scale of $1: 24,000$ for overlay onto topographic maps of the study area. Mapwork and field surveys were used to identify five spatially 
distinct examples of each meadow type at least 250 $\mathrm{m}$ apart. Sample sites were located in the field with the aid of global positioning devices, aerial photography, topographic maps, and compass readings from identifiable landmarks. Particular care was taken to ensure that sites were located in the center of a class.

We had originally intended to stratify meadows by size classes, but this was not possible because several of the M-types did not exist within a broad range of sizes. Instead, we stratified by northern and southern portion of the ecosystem, allowing for a comparison between regions. There were some problems associated with the M4 classification in the Teton region. Field investigations in late May indicated that areas mapped as M4 meadow types were in fact groves of aspen (Populus tremuloides) with dense herbaceous understories. These groves were not identifiable as such on the satellite imagery. Since the focus of this research was on non-forested montane meadows, and there is no close corollary to these groves in the Gallatin region (aspen is nearly nonexistent in that area), the M4 type was eliminated from the Teton region, and sampling proceeded in the remaining five meadow types. Thus we established 55 sampling sites for 1997 and 1998 (two study regions, six habitat types, five replicates per habitat type (except for M4's in Tetons)). See Appendix 1 for details of site locations. In 1999 we established 8 new sites in the Tetons per mtype (total of 40 sites) and 5-6 new sites in the Gallatins (6 of all mtypes except M3 and M4, which had 5 new sites; total of 34 new sites). These sites were selected based on accessibility (within $7 \mathrm{~km}$ of the road) and elevation (2000 - $2500 \mathrm{~m})$.

\section{Establishment of Sampling Sites}

A single point was established at each of the sample sites. This point was located in an area reasonably typical (not anomalous) for each particular meadow, and in smaller meadow polygons was located near the center of the meadow so as to avoid edge effects. This point was the northwest corner of a $20 \times 20 \mathrm{~m}$ plot used for botanical and plant biomass sampling. The $20 \times 20$ $m$ plots were then established using four steps: a) The southwest corner was established by measuring $20 \mathrm{~m}$ due south from the northwest corner. b) The approximate location of the southeast corner was then located by measuring $20 \mathrm{~m}$ due east from the southwest corner. c) Triangulation was used to insure that the plot was square, and the southeast corner was located correctly. A hypotenuse of 28.3 $\mathrm{m}$ was measured from the northwest corner to the southeast. The southeast corner was established where the hypotenuse met the $20 \mathrm{~m}$ measurement from step two. d) The a pproximate location of the northeast corner was located by measuring $20 \mathrm{~m}$ due north from the southeast corner. Once again, triangulation was used to insure that the plot was square. The northeast corner was established at the point $20 \mathrm{~m}$ from the southeast corner and $20 \mathrm{~m}$ from the northwest corner. A $100 \times 100 \mathrm{~m}$ plot was overlaid upon the $20 \times 20 \mathrm{~m}$ plot, using the NW corner of the smaller plot as the center point. One of the four $50 \times 50$ m quadrats within the $100 \times 100 \mathrm{~m}$ area was randomly selected to be used as the butterfly survey plot. Bird surveys were conducted in a $50 \mathrm{~m}$ radius circular plots using the midpoint of the $100 \times 100 \mathrm{~m}$ plot and flags were used to mark edges of the circular plot in at least 3 of the cardinal directions. Observers surveying birds stood just off the center of the $100 \times 100 \mathrm{~m}$ point, to avoid trampling the plants in the vegetation plots.

Each of the fifty-five $20 \mathrm{~m}$ by $20 \mathrm{~m}$ plots sampled in 1997 \& 1998 was marked to facilitate relocation of plots in subsequent years. The northwest corner of each plot is marked with a 1.25 $\mathrm{m}$ steel or wooden post. All four corners of each plot were marked with a $0.3 \mathrm{~m}$ piece of buried steel rebar, which can be relocated with a metal detector. Because each plot was permanent and can be relocated, data can be used to track individual plants and species over time. A permanent and repeatable technique helps to insure that year to year species changes are indeed due to shifts in plant community composition rather than sampling error.

\section{Biophysical and spectral field sampling}

Plant biomass measurements were made in July of 1997-1999 for both Teton and Gallatin study areas. Measurements were scheduled to be coincident with satellite overpass days when possible. For each plot, three $0.20 \times 0.50 \mathrm{~m}\left(0.1 \mathrm{~m}^{2}\right)$ quadrats were spaced at $10.0 \mathrm{~m}$ intervals along the northern edge of each $20 \times 20 \mathrm{~m}$ plot. All aboveground green photosynthetically active vegetation within each quadrat was clipped, sorted by life form/category (grasses, forbs, and shrubs), placed in paper bags, and immediately weighed in the field using spring scales to the nearest 1.0 gram to determine "wet" weight. In the lab, bags were dried in a laboratory oven at 100 degrees $\mathrm{F}$ for 48 hours, and weighed again to determine "dry" weight and percent moisture by life form. In 1999, in addition to revisiting and resampling the sites sampled in 1997 and 1998, we also sampled a set of 


\begin{tabular}{|l|l|l|l|l|l|l|l|l|}
\hline \multicolumn{7}{|c|}{ Table 1. SPOT multispectral satellite imagery acquired for project } \\
\hline & \multicolumn{9}{|c|}{ Teton } & Summer & $\begin{array}{l}\text { Late } \\
\text { Summer }\end{array}$ & Fall & Spring & Summer & $\begin{array}{l}\text { Late } \\
\text { Summer }\end{array}$ & Fall \\
\hline & Spring & $n d a$ & $n d a$ & $n d a$ & $5 / 25$ & $7 / 17$ & $9 / 6$ & $n d a$ \\
\hline 1994 & $n d a$ & $6 / 17$ & $9 / 03$ & $n d a$ & $n d a$ & $n d a$ & $n d a$ & $n d a$ \\
\hline 1996 & $n d a$ & $7 / 04$ & $8 / 30$ & $10 / 06$ & $c c$ & $7 / 14$ & $8 / 30$ & $9 / 25$ \\
\hline 1998 & $c c$ & iae & iae & iae & $c c$ & $7 / 12$ & $8 / 28$ & $c c$ \\
\hline 1999 & $c c$ & $7 / 06$ & $c c$ & $9 / 22$ & $c c$ & $7 / 06$ & $c c$ & $9 / 22$ \\
\hline 2000 & $c c$ & $n d a$ & $n d a$ & $n d a$ & $c c$ & $n d a$ & $8 / 16$ & $n d a$ \\
\hline
\end{tabular}

5-6 additional meadow sites within each meadow class, for a total of 140 sites sampled (new and repeat) for 1999 .

Measurements of leaf area index (LAI) were made in meadows in 1997 and 1999 using a LiCor LAI-2000 system. At each plot, samples were taken; one in each of the four plot corners and one in the center of the plot. Each sample consisted of an above-canopy calibration reading and three below-canopy readings. Whenever possible, readings were made with the sun obscured (diffuse daylight), either from a low sun angle (sunrise or sunset), a passing cloud, or by manual shading. The five samples were then averaged to obtain a representative LAI measurement for each site.

Spectral reflectance readings were taken in 1997 and 1998 using an Analytical Spectral Devices (ASD) spectroradiometer, recording electromagnetic energy reflected by the surface over the range $0.3265-1.05533 \mathrm{~m}$ (visible and near-infrared light) in 512 discrete spectral bands. Measurements were taken for each of the twenty $1 \times 1$ m quadrats used for botanical assessment. Ten spectroradiometer scans per quadrat were acquired and internally averaged by the system to determine spectral reflectance. All sites were sampled between 0900 and 1550 hours local solar time. A white reference calibration reading was made at the start of each plot to normalize all reflectance values to a common standard. Sites in Teton region were sampled during the period July 2-7 (coincident with SPOT satellite image acquisition) and on July 20-23 for the Gallatin study area.

SPOT multispectral satellite imagery were acquired by the SPOT satellite in summer, late summer, and fall for both Teton and Gallatin regions
(Table 1). Excessive cloud cover over both study regions during May and June in all years precluded satellite image acquisition for spring seasons. Satellite data acquisitions in 1998 and 1999 were near-anniversary dates with data acquired for 1997 , facilitating interannual comparison of vegetation condition and development. All summer dates were coincident with field sampling.

Computation of seasonal and interannual changes in greenness

Red and near-infrared reflectance has been used to measure vegetation condition, based on the negative relationship between red reflectance and chlorophyll content, and the positive relationship between leaf structure and near-infrared (NIR) reflectance (Jensen, 1983; Curran, 1985). The Normalized Difference Vegetation Index (NDVI) is calculated using the red and near-infrared bands, using the equation [NDVI = (NIR$\mathrm{RED}) /(\mathrm{NIR}+\mathrm{RED})]$. NDVI values are often referred to as "greenness" values because they have been shown to be well-correlated $w$ ith vegetation c over, fraction of photosynthetically active radiation ( $f$ PAR) absorbed by green foliage, leaf area index (LAI), and biomass (Bartlett et al., 1990; Duncan et al., 1993; Hope et al., 1993; Goward et al., 1994; Everitt et al., 1996; Jorgensen and Nohr, 1996; Jakubauskas et al., in press). Furthermore, seasonal and interannual changes in NDVI are increasingly used to monitor natural and anthropogenic changes in vegetation communities (Lloyd, 1990; Reed et al., 1994; Lancaster et al., 1996; Peters et al., 1997).

An NDVI was computed for each pixel of each date of imagery. Seasonal changes in greenness for 1994, 1997, and 1998 were computed by subtracting the earlier seasonal date in each year 


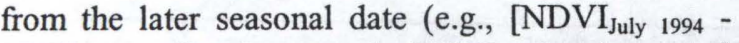

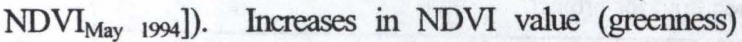
between two dates were therefore expressed as positive values, and decreases in NDVI as negative values. A similar procedure was used to compute interannual NDVI change for the three mid-summer (July) NDVI images (1994-1997, 1997-1998). NDVI change values for each field sampled site were extracted from each image using the UTM coordinates for each site. Tests for changes in NDVI (both seasonally and interannually) were conducted using a Scheffe's ANOVA (PROC ANOVA; SAS Institute 1990).

\section{Vegetation Sampling Techniques}

During 1997-1998, plants were surveyed at three scales: $1 \mathrm{~m}^{2}, 20 \times 20 \mathrm{~m}^{2}$ and $100 \times 100 \mathrm{~m}^{2}$. During 1999, a larger number of sites were surveyed, but plant cover was estimated only at the $20 \times 20 \mathrm{~m}^{2}$ scale. Twenty $1 \mathrm{~m}^{2}$ quadrats were located systematically within each $20 \times 20 \mathrm{~m}$ plot. The quadrats were arranged in four belt transects of five quadrats each. All belt transects ran west to east, and quadrats were $4 \mathrm{~m}$ apart. Field measuring tapes were laid in a grid-like fashion to insure correct locations of transects and quadrats. The first transect was located along the line between the northwest and northeast corners of the $20 \times 20 \mathrm{~m}$ plot. The second, third and fourth transects were respectively located $5 \mathrm{~m}, 10 \mathrm{~m}$, and $15 \mathrm{~m}$ south of the first transect. Along each transect, the northwest corner of the $1 \mathrm{~m}^{2}$ quadrats were located at $3 \mathrm{~m}, 7 \mathrm{~m}$, $11 \mathrm{~m}$, and $15 \mathrm{~m}$ from the east edge of the $20 \times 20 \mathrm{~m}$ plot. The nested sampling design allowed for detailed data collection within the $20 \times 20 \mathrm{~m}$ plot, and the systematic layout insured that the quadrats were relocatable and that sampling could be accurately repeated in subsequent years.

For each $1 \mathrm{~m}^{2}$ quadrat, the aerial percent cover of all plant species was estimated during our July sampling period to derive a measure of plant species composition. After the $1 \mathrm{~m}^{2}$ plots were sampled, the entire $20 \times 20 \mathrm{~m}$ plot and the $100 \times 100$ $\mathrm{m}$ plot were sampled for cover. This sampling provided us with data at 3 scales and with the middle scale $(20 \times 20 \mathrm{~m})$, being of the actual pixel size of the remote sensing data. Aerial cover estimations were conducted using a modified Daubenmire (1959) method in which estimations were made to the nearest percent. The combined cover of litter and bare ground was also estimated using estimated percent cover. This sampling technique is advantageous because it provides a measure of both species richness and species abundance. Percent cover provides valuable data since it can indicate both plant size and number of individuals.

All plants were identified to species in the field or given appropriate field names. Voucher specimens were collected for all species so that accurate identifications could be made. Species that were difficult to identify were reviewed by botanists at the University of Kansas Herbarium where the vouchers are housed.

\section{Species distribution patterns of birds and butterflies}

Abundance data were collected for butterflies and birds in each of the sampling sites. Birds were surveyed between 0530-1030 hrs using point counts in $100 \mathrm{~m}$ diameter circular plots. Two observers were present for each 15 min survey. One point count was conducted at each site. Butterflies were surveyed between $0930-1630 \mathrm{hrs}$ by two people netting for 20 minutes in $50 \times 50 \mathrm{~m}$ plots at each sampling site. Each butterfly was placed in a glassine envelope and at the end of the survey all individuals of each species were tallied and most were released. A subset of butterflies were taken as voucher specimens.

Bird data were collected during each of the four years from early June 1 to mid-July, when most songbirds stopped singing. Butterfly data were collected during each of the four years from midJune to mid-August. Collection earlier than these dates was prohibited by cold weather. During 199798 , bird data were collected three times per year at each sampling site in each of the two study regions. Butterfly data were collected four times per year in each region. In 1999, bird data were collected once at the core sites and twice in the additional sites in the Gallatin and the Teton study regions. During 2000 , bird data were collected twice in the core and twice in the new sites. During 1999-2000, butterfly data were collected twice in both core and additional sites in each region. Data collections in each of the two regions alternated every two weeks to ensure that species with phenologically different emergence times or activity periods would be included in both data sets. All specimens were identified to species in the field or given appropriate field names. Voucher specimens of butterflies were collected so that accurate identifications could be made. Species that were difficult to identify were reviewed by Steve Kohler, an authority on Montana lepidopterans. Voucher specimens are housed at Iowa State University. 
Testing three scales of remotely sensed habitat classifications as coarse-filters for biodiversity conservation

Habitat classifications developed from remote-sensing data and geographic information systems (GIS) have become the cornerstone of many coarse-filter biodiversity planning efforts. An untested assumption of this approach is that map class is an accurate surrogate of distinct biotic communities. We used the 1997 and 1998 bird, butterfly and plant field data to test this assumption across three scales of habitat classifications. The finest resolution map was the 1 ha minimum mapping unit (MMU) M-Type map. This was compared to the 100 ha MMU Wyoming Gap analysis project (GAP) vegetation map in the Teton region and the 2 ha MMU Montana GAP in the Gallatin region. We used multivariate measures of community similarity (Bray-Curtis distance) and non-parametric permutation tests (ANOSIM) to test whether map classes were adequate surrogates for distinct communities. We concluded that a map was associated with distinct communities if species composition of birds, butterflies, and plants was significantly more similar within habitat classes than between habitat classes.

\section{$+\quad$ Results}

Here we report on analyses focusing on core sites primarily during 1997-1998, those data for which the most extensive analyses have been completed.

\section{Plant Community}

We surveyed vegetation for three years for all locations for plant cover. Data from the 19971999 field seasons were entered into a database and all measures of quality control were performed during the winter of 1997-1999. Although there were differences between the Gallatins and the Teton sites, meadow types were generally fairly consistent in the composition by dominant species with M1 and M2s being dominated by Salix spp and Carex rostrata. M3 and M4 types were dominated by Poa pratensis and Artemisia tridentata, and M5 and M6 types being dominated by Festuca idahoensis and Artemisia tridentata. The data for the $\mathrm{M} 1$ and $\mathrm{M} 2 \mathrm{~s}$ are indicative of wetlands and the wetland index that we use (Kindscher et al. 1998) show wetland index values below 3.00 (documenting cover dominated by wetland plants) for these meadow types for both the Gallatin and
Teton sites for all years. Comparisons of plant community composition between the Gallatins and the Tetons, using the Bray-Curtis distance measure, showed that statistical differences only occurred for the driest communities in the M5 and M6 meadow types. We believe that this occurred due to species differences between the warmer and more southerly Tetons when compared to the cooler Gallatin Range sites in Montana. Overall, the vegetation classification was accurate is discerning the meadow types and classifying them accurately.

\section{Bird Community}

We surveyed bird communities for four years using point counts. Overall, there were major differences in the bird community between regions. For example, there was $59 \%$ similarity between the Gallatins and the Tetons in 1997 and only $47 \%$ similarity in 1998. Results from Fisher's Exact tests comparing species composition between the Gallatins and Tetons indicated that all 5 meadow types were significantly different between regions in both years $(\mathrm{p}<0.05)$. Species composition was also compared between regions using a Kappa statistic. Three of 5 meadow types were statistically different between study areas in both years, but two of the meadow types had changed significance from the previous year. Species composition in the most hydric meadow type was the only data set that could be accurately predicted in both study areas. However, there were major differences in abundance of individual species that may be confounding these results. Overall, Teton bird abundances were much higher than those of the Gallatins. A comparison of Gallatin and Teton bird communities using a canonical discriminant analysis showed that each of the meadow types from the two regions clustered quite well in 1998.

We also compared the accuracy of predicting the occurrence of a subset of 11 bird species in montane meadows using a combination of remotely sensed, landscape, and habitat data (Saveraid et al., in press). Meadow type, as determined from the remotely sensed data, was highly correlated with abundances of six of the 11 bird species. Abundances of generalist species were not strongly correlated with landscape variables or meadow type. Abundances of the species commonly associated with hydric meadows [Common Snipe (Gallinago gallinago), Common Yellowthroat (Geothlypis trichas), Lincoln's Sparrow (Melospiza lincolnii), Savannah Sparrow (Passerculus sandwichensis), and Yellow Warbler (Dendroica petechia)] were significantly correlated 
with meadow type and landscape variables such as percent willow cover and percent woody vegetation. There were fewer species in the xeric meadows, but the most commonly observed species, the Vesper Sparrow (Pooecetes gramineus), was highly correlated with meadow type and percent sagebrush cover. The results from our study indicate that remotely sensed data are applicable for estimating potential habitats for bird species in the different types of montane meadows. However, for fine-scale information about species in specific sites or areas, we recommend the use of additional landscape and habitat data collected in the field.

\section{Butterfly Community}

Eighty-two species were found across both sampling areas during 1997 and 1998, and the species similarity between the two areas was $65 \%$. Butterfly distributions were much more strongly associated with specific meadow types in the Teton landscape relative to the Gallatin landscape. Using species abundance data for each meadow type, classification trees were used to identify species that were most important in distinguishing among meadow types. Of the 67 butterfly species found during our surveys in the Tetons, 20 species in 1997 and 27 species in 1998 were used in the statistical analysis. Fourteen species were defined as important in distinguishing among meadow types, and these species could be used to classify sampling sites into one of five different meadow types with 96\% accuracy in 1998 and a $92 \%$ accuracy in 1997. Six species showed high importance scores for both years in the Tetons. Each species is listed followed by the meadow type for which it showed a high affinity: Coenonympha orchracea (M6), Lycaena heteronea (M6), Coenonympha haydenii ( M5), Cercyonis oetus (M3), Speyeria mormonia (M3), and Boloria frigga (M2). Predictability of species was much lower $(63 \%)$ in the Gallatins, where patch size is much smaller, but many of the same species showed high importance scores in differentiating the meadows (Borgognone 1999).

\section{FRAGSTATS analysis}

FRAGSTATS spatial analysis program was applied to the Arc/Info GIS coverage of meadow habitat classifications to calculate parameters such as meadow size, distance to next meadow of the same type, and average distance to all meadows of a specific type. Meadows in the Tetons are 10 times larger on average than meadows in the Gallatins (132.8 ha versus $12.9 \mathrm{ha}$ ) and landscape context may have significant effects on bird and butterfly species distribution patterns (possibly explaining some of the differences between the sampling regions).

Geostatistical Analysis of meadows in SPOT imagery

Two approaches were evaluated to test relationships between landscape heterogeneity and species diversity. Our objective was to characterize the spatial variability of habitat surrounding each sampled meadow site and relate the patterns of spatial/spectral variability (texture) to patterns of animal (bird and butterfly) species and diversity. The techniques involved a contextual analysis of nominal-scale land cover surrounding each sampled meadow location; and a semivariance analysis of NDVI images from multispectral SPOT data acquired during spring, summer, and fall of 1994. Results indicate significant difference in spatial variability across the six meadow types, and indicate that the occurrence of several species of birds and butterflies are correlated with semivariance and standard deviation values at specific lag distances from the meadow centroid. Correlating species abundance with semivariance showed that redwinged blackbirds were significantly correlated with a lag distance of 50-100 m (indicating an edge preference), the common snipe with a lag distance of 150-200 m, and Common Yellowthroat with lag distances of $150-400 \mathrm{~m}$ (indicating a preference for more open areas). Standard deviation windowing indicated that abundance values for the mountain chickadee were significantly correlated with standard deviation values at $125 \mathrm{~m}$, the YellowRumped Warbler at a lag distance of $150 \mathrm{~m}$, and the Vesper Sparrow at a lag distance of $250 \mathrm{~m}$. The semivariance and standard deviation windowing techniques show great promise both for characterizing the quality of habitat for particular species, and for using spatial measures of satellite imagery for predicting the occurrence of specific species.

\section{Wetlands}

Our technique for finding wetland communities (M1 and M2 meadows) has been greatly improved by the research methods we have developed during our study. Using our remotely sensed data and previously collected vegetation data, we developed a new procedure for identifying wetlands using average wetland values. Using these techniques, we identified 1,250 hectares of M1 wetland meadows and 1,711 hectares of slightly drier M2 wetland meadows in Grand Teton National 
Park (Kindscher et al. 1998).

\section{Climate Change}

We hypothesized that mesic meadows would support the highest species diversity of plants, birds, and butterflies because they are more moderate environments. We also hypothesized that mesic meadows would exhibit the greatest seasonal and interannual variability in spectral response across years. Our results showed that mesic meadows supported the highest plant species diversity, but there was no significant difference in bird or butterfly species diversity among meadow types. These data show that it may be easier to detect significant differences in more species rich taxa (e.g., plants) than taxa that are represented by fewer species (e.g., butterflies and birds). Mesic meadows also showed the greatest seasonal and interannual variability in spectral response. Given the rich biodiversity of mesic montane meadows and their sensitivity to variations in temperature and moisture, they may be important to monitor in the context of environmental change.

Testing three scales of remotely sensed habitat classifications as coarse-filters for biodiversity conservation

We found that both the 1 ha MMU M-Type map and 100 ha MMU Wyoming GAP map were significantly associated with bird, butterfly and plant community similarity ( $\mathrm{Su}$ et al. in review). However, the 2 ha Montana GAP map was not associated with bird and plant community similarity and only discriminated differences in butterfly species composition between one map class and the others. The primary difference between the Montana GAP map and the other maps was a coarser categorical resolution (smaller number of habitat categories) which was not sensitive to community variation associated with the hydrology of the meadows. These results suggest that the appropriate categorical resolution of a map may be as important as the spatial resolution of a map to adequately represent distinct biotic communities.

\section{Seasonal and interannual variation in NDVI}

Seasonal changes in spectral reflectance at local scales are a function of the species composition and the environmental conditions of a site (Kremer and Running 1993, Senseman et al. 1996, Everitt and Escobar 1996). Changes in spectral reflectance patterns, therefore, may signal changes in vegetation structure or composition, or changes in environmental conditions that later may trigger changes in the vegetation. If seasonal and interannual patterns of spectral response can be linked to distinct plant species assemblages, this may provide a means to predict potential plant and animal species diversity (Walker et al. 1992, Stoms and Estes 1993, Jorgenson and Nohr 1996, Nagendra and Gadgil 1999). The objectives of this section were to 1) characterize the seasonal and interannual spectral variability of six classes of montane meadow vegetation communities along a moisture gradient (from hydric to mesic to xeric). We hypothesized that mesic meadows would exhibit the greatest seasonal and interannual variability in spectral response across years. Here we present data from an analysis of the Gallatin region only.

\section{Seasonal change}

In the Gallatin region, the annual minimum and maximum temperature ranges between $-15^{\circ} \mathrm{C}$ (December) and $25^{\circ} \mathrm{C}$ (August), and the average monthly precipitation ranges between $2.0 \mathrm{~cm}$ to 7.0 $\mathrm{cm}$, peaking in late spring/early summer (MayJune). Average total annual snowfall exceeds $3 \mathrm{~m}$, with January receiving the greatest average monthly accumulation at slightly less than $1 \mathrm{~m}$. Onset of vegetation greenness in meadows occurs by mid to late May, depending on seasonal variations in snowfall depth and spring temperatures. Grasses and forbs progress at a more rapid phenological rate than shrubs in this region, initiating greenup and senescence earlier in the season (Blaisdell, 1958). Vegetation greenness is at a maximum in early to mid July, and by late August to early September, most non-forested vegetation communities have ceased photosynthetic activity for the growing season.

Temperature and precipitation data obtained from the Western Regional Climate Center for Montana Climatological Division 2 indicate that above average temperatures and below average precipitation occurred throughout the summer and fall of 1994 (Table 2). In contrast, warmer than average temperatures and higher than normal precipitation during spring and summer 1997 accelerated the rate of plant growth and development in the region. Significantly cooler and wetter than normal conditions in June 1998, however, led to delayed phenology and plant development during spring and early summer.

Trends of seasonal change in greenness for all three years indicate that the mesic meadow types exhibit the greatest overall change between 
midsummer and fall, while xeric meadows exhibit

\begin{tabular}{|c|c|c|c|c|c|c|c|c|}
\hline \multicolumn{9}{|c|}{$\begin{array}{l}\text { Table } 2 \text { Summer temperature and precipitation, } \\
\text { Southwestern Division } 1994,1997,1998 \text {, and mean values }\end{array}$} \\
\hline & \multicolumn{2}{|c|}{ May } & \multicolumn{2}{|c|}{ June } & \multicolumn{2}{|c|}{ July } & \multicolumn{2}{|c|}{ August } \\
\hline \multicolumn{9}{|c|}{ Temperature $\left({ }^{\circ} \mathrm{C}\right)$} \\
\hline 199 & 11.0 & $(+2.2$ & 13. & $(+0.8$ & 17. & $(-0.1)$ & 17.8 & $(+1.6$ \\
\hline 199 & 10.4 & $(+1.6$ & 14. & $(+1.0$ & 16. & $(-0.8)$ & 16.2 & $(0.0)$ \\
\hline 199 & 9.6 & & în. & $(-2.5)$ & 18. & $(+1.6$ & 17.8 & $(+1.5$ \\
\hline 189 & 8.8 & & 13. & & 17. & & 16.2 & \\
\hline \multicolumn{9}{|c|}{ Precipitation $(\mathrm{cm})$} \\
\hline 1994 & 4.6 & $(-1.2)$ & 5.6 & $(-0.7)$ & 3.8 & $(+0.2$ & 1.4 & $(-1.7)$ \\
\hline 1997 & 6.1 & $(+0.2$ & 8.7 & $(+2.3)$ & 6.5 & $(+2.9$ & 4.7 & $(+1.6$ \\
\hline 1998 & 5.4 & $(+0.4$ & 10. & $(+3.7)$ & 3.6 & $(+0.1$ & 1.7 & $(-1.4)$ \\
\hline $\begin{array}{c}1895 \\
- \\
\text { (Numbers i }\end{array}$ & 5.9 & eses & $\dot{6} .3$ & en & 3.5 & 、 & 3.1 & \\
\hline
\end{tabular}

little year-to-year variation in the summer-fall decrease in greenness (Figure 1). In 1994, belowaverage precipitation for the summer and early fall produced severe moisture stress across all meadow types and a high degree of greenness change for hydric meadow types and the mesic meadows. M4 meadows showed significantly more change in greenness compared to M5 meadows ( $\mathrm{P}<0.05$, $\mathrm{F}=6.26, \mathrm{df}=5,24)$. In contrast, xeric meadows, with vegetation adapted to dry conditions, exhibited the least seasonal greenness change in 1994. Under wetter conditions (1997 and 1998), the hydric meadows showed less seasonal change, while the mesic meadows continued to exhibit large changes in summer-to-fall greenness values (Figure 1). In 1997, M3 and M4 meadows showed significantly more change in greenness compared to M5 meadows $(\mathrm{P}<0.05, \mathrm{~F}=4.44, \mathrm{df}=5,24)$. In $1998, \mathrm{M} 3$ and M4 meadows showed significantly more change in greenness compared to M1 meadows, and M4 meadows showed significantly more change in greenness compared to $\mathrm{M} 2$ meadows $(\mathrm{P}<0.05$, $\mathrm{F}=6.315, \mathrm{df}=5,24)$.

Differences between the three years are suggestive of strong environmental controls, particularly temperature and precipitation, on changes in meadow greenness. Hydric meadows in the study region tend to occur along streams and rivers that provide the vegetation with a constant source of moisture. Xeric meadows are typically on south-facing slopes, with near-constant moisture deficits producing sparse vegetation cover and little change in greenness. Mesic meadows, however, are dominated by a high percentage cover of grasses and forbs that are more dependent on precipitation for moisture.

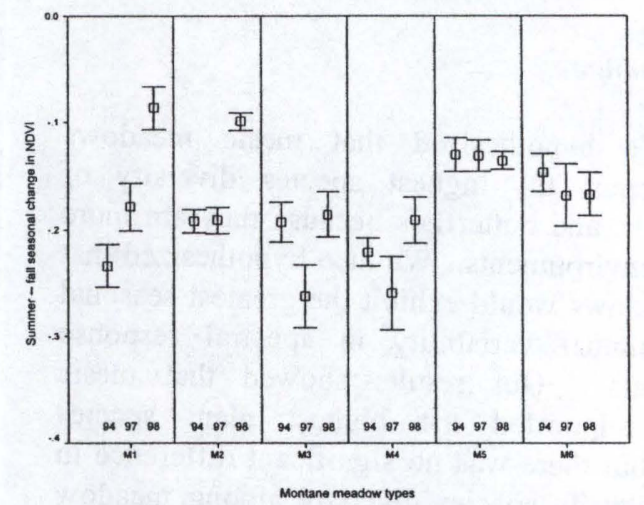

Figure 1. Seasonal change in NDVI (mean and standard error) for Gallatin sites in 1994, 1997, and 1998. More negative values indicated greater seasonal decreases in greenness from summer to fall.

\section{Interannual change}

Overall, the mesic M3 and M4 meadows exhibited the greatest range in interannual change in midsummer greenness of the six meadow types when comparing the periods 1994-1997 and 199798 (Figure 2). Comparing greenness values for midsummer 1994 to midsummer 1997, all meadows were substantially greener in 1997 than 1994. Of the mesic meadows, the M4 meadows exhibited a significantly larger interannual change in NDVI (1994-1997) than M1 and M2 meadows $(\mathrm{P}<0.05$, $\mathrm{F}=4.824, \mathrm{df}=5,24)$. We attribute these greenness changes to differences in early summer precipitation between the two years. Combined May-June precipitation for 1994 was $1.9 \mathrm{~cm}$ lower than normal; May-June precipitation for 1997 was $2.5 \mathrm{~cm}$ above normal (Table 2). Temperatures for both periods were warmer than the long-term mean (mean MayJune 1994: $+1.5^{\circ} \mathrm{C}$; mean May-June 1997: $\left.+1.3^{\circ} \mathrm{C}\right)$. Comparing greenness values for midsummer 1997 to midsummer 1998 , however, the hydric and xeric meadows showed little difference in 1997 and 1998 midsummer greenness values (Figure 2). Mesic meadows exhibited lower greenness values in summer 1998 than summer 1997, which we attribute, based on field observations, to vegetation development occurring slightly later in the growing season, likely a result of cooler than normal temperatures and above-average rainfall in early summer (June) 1998 (Table 2).

\section{SUMMARY}

This research has provided significant new insights into montane meadow community composition and dynamics. We have identified 
species plant and animal communities associated with each of six meadow types arrayed along a hydrological gradient. Although there were differences between our two sampling regions which precluded predictions at the community

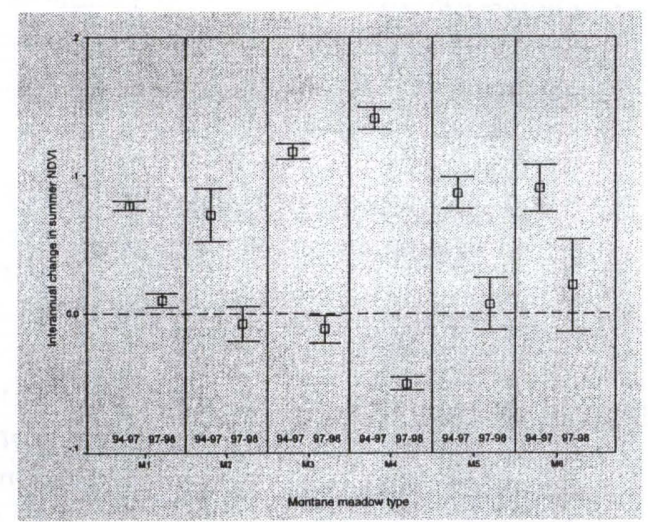

Figure 2. Interannual change in summer greenness for Gallatin sites 1994-1997 and 1997-1998. Positive values indicate that all meadows were substantially greener in 1997 than 1994 . With the exception of M4 meadows, meadows showed little difference between 1997 and 1998 midsummer NDVI values.

level by meadow type, there were predictable similarities between regions, especially with respect to the composition of the most common species in each meadow type. We also explored the seasonal and interannual variation in spectral response associated with each of these six meadow types. Our results show that mesic meadows and their associated plant and animal communities may be some of the most important habitats to monitor in the context of global climate change for Rocky Mountain ecosystems.

\section{ACKNOWLEGEMENTS}

Funding for this research was provided by the U.S. Environmental Protection Agency, National Center for Environmental Research and Quality Assurance (NCERQA), STAR Grant R825155. Although the research described in this article has been funded in part by the EPA, it has not been subjected to the Agency's peer review and therefore does not necessarily reflect the views of the Agency, and no official endorsement should be inferred. Field assistance was provided by $\mathrm{E}$. Saveraid, T. Saveraid, C. Blodgett, A. Fraser, J. Auckland, D. Friederick, T. Aschenbach, S. Ashworth, H. Loring, J. Hanlon, J. Pritchard, and others.

\section{LITERATURE CITED}

Bartlett, D. S., W hiting, G. J., and H artman, J. M. 1990. Use of vegetation indices to estimate intercepted solar radiation and net carbon dioxide exchange of a grass canopy. Remote Sensing of Environment 30:115128.

Blaisdell, J. P. 1958. Seasonal development and yield of native plants in the upper Snake River Plains and their relation to certain climatic factors. U.S. Department of Agriculture Technical Bulletin 1190.

Borgognone, M.G., D.M. Debinski, M. Jakubauskas, and K. Kindscher. 1999. Use of CART and canonical discriminant analysis to select variables and classify cases in a situation with few observations and many variables. Proceedings of the Fourth Conference of Latin-American Statistical Societies. Mendoza, Argentina, July 26-30, 1999.

Curran, P. 1985. Multispectral remote sensing of vegetation amount. Progress in Physical Geography 9:315-341

Daubenmire, R.F., 1959. Canopy coverage method of vegetation analysis. Northwest Science, $33,43-64$.

Duncan, J., Stow, D., Franklin, J., and Hope, A. 1993. Assessing the relationship between spectral vegetation indices and shrub cover in the Jornada Basin, New Mexico. International Journal of Remote Sensing 14:3395-3416.

Everitt, J. H., and D. E. Escobar. 1996. Use of spatial information technologies for noxious plant detection and distribution on rangelands. Geocarto International 11:6380.

Everitt J. H., Escobar, D. E., Alaniz, M. A., and Davis, M. R. 1996. Comparison of ground reflectance measurements, airborne video, and SPOT satellite data for estimating phytomass and cover on rangelands. Geocarto International 11:69-76. 
Goward, S. N., Waring, R. H., Dye, D. G., and Yang, J. 1994. Ecological remote sensing at OTTER: Satellite macroscale observations. Ecological Applications 4:322-343.

Harte, J and Shaw, R.: 1995. Shifting dominance within a montane vegetation community results of a climate-warming experiment. Science 267: 876-880.

Hope, A. S., Kimball, J. S., and Stow, D. A. 1993. The relationship between tussock tundra spectral reflectance properties and biomass and vegetation composition. International Journal of Remote Sensing 14:1861-1874.

Jakubauskas, M. E., Kindscher, K., and Debinski, D. M. In press. Spectral and biophysical relationships of montane sagebrush communities in multitemporal SPOT XS data. International Journal of Remote Sensing.

Jensen, J. R. 1983. Biophysical remote sensing. Annals of the Association of American Geographers 73:111-132.

Jorgensen, A. F. and Nohr, H. 1996. The use of satellite images for mapping of landscape and biological diversity in the Sahel. International Journal of Remote Sensing 17:91-109.

Kindscher, K., A. Fraser, M.E. Jakubauskas, and D.M. Debinski. 1998. Identifying wetland meadows in Grand Teton National Park using remote sensing and average wetland values. Wetlands Ecology and Management 5:265-273.

Knight, D. H. 1994. Mountains and Plains: The Ecology of Wyoming Landscapes. Yale University Press, New Haven, Connecticut.

Kremer, R. G. and Running, S. W. 1993. Community type differentiation using NOAA/AVHRR data within a sagebrushsteppe ecosystem. Remote Sensing of Environment. 46:311-318.
Lancaster, J., Mouat, D., Kuehl, R., Whitford, W., and Rapport, D. 1996. Time series satellite data to identify vegetation response to ecosystem stress as an indicator of ecosystem health. Proceedings, Shrubland Ecosystem dynamics in a Changing Environment. General Technical Report INT-GTR-338. Ogden, UT. U.S. Department of Agriculture, Forest Service, Intermountain Research Station.

Lloyd, D. 1990. A phenological classification of trrestrial vegetation cover using shortwave vegetation index imagery. International Journal of Remote Sensing 11:2269-2279.

McGarigal, K. and Marks, B.J. 1994. FRAGSTATS: spatial pattern analysis program for quantifying landscape structure. Version 2.0.

Nagendra, H. and Gadgil, M. 1999. Biodiversity assessment at multiple scales: Linking remotely sensed data with field information. Proceedings of the National Academy of Sciences of the USA 96:91549158.

Peters, A. J., Eve, M. D., Holt, E. H., and Whitford, W. G. 1997. Analysis of desert plant community growth patterns with high temporal resolution satellite spectra. Journal of Applied Ecology 34:418-432.

Reed, B.C., Brown, J. F., VanderZee, D., Loveland, T. R., Merchant, J. W., and Ohlen, D. O. 1994. Measuring phenological variability from satellite imagery. Journal of Vegetation Science 5:703-714.

Romme, W. H., and Turner, M. G. 1991. Implications of global climate change for biodiversity in the Greater Yellowstone Ecosystem. Conservation Biology 5:373386.

SAS Institute, Inc. 1990. SAS/STAT User's Guide, Release 6.03 edition. SAS Institute, Inc. Cary, NC 163 pp. 
Saveraid, E. H. 1999. Using satellite imagery and landscape variables to predict bird communities in montane meadows of the Greater Yellowstone Ecosystem. M.S. Thesis, Ecology and Evolution Biology Program, Iowa State University, Ames, Iowa.

Senseman, G. M., Bagley, C. F., and Tweddale, S. A. 1996. Correlation of rangeland cover measures to satellite-imagery-derived vegetation indices. Geocarto International 11: 29-38.

Stoms, D. M. and Estes, J. E. 1993. A remote sensing research agenda for mapping and monitoring biodiversity. International Journal of Remote Sensing 14:1839-1860.
Su, Jeffrey C., Debinski, D.M., M.E. Ja kubauskas, and K. Kindscher. (Submitted). Testing three scales of remotely sensed habitat classifications as coarse-filters for biodiversity conservation. Ecological Applications.

Walker, R. E., Stoms, D. M., Estes, J. E., and Cayocca, K. D. 1992. Relationships between biological diversity and multitemporal vegetation index in California. ASPRS Technical Papers, 1992 ASPRS-ACSM Annual Meeting Vol. 1, pp. 562-571. 
Appendix 1. Locations of sites in Gallatin National Forest and northwestern Yellowstone National Park (Gallatin) and Grand Teton National Park , Teton). Sites designated with a "gm" are used to identify Gallatin sites, whereas sites designated with a "tm" are used to designate Teton sites. The number of the code represents the meadow type (i.e m1-m6), and the letter designates the spatial replicate. Sites that end in letters a-e are considered the "core sites" which were surveyed each year, whereas sites with other designations were considered the additional sites and were only surveyed in 1999 for birds, butterflies, and plants and 2000 for butterflies and plants. UTM x is the easting whereas UTMy is the northing. The Quad is the 7.5 minute USGS map on which the site can be found.

\begin{tabular}{|c|c|c|c|}
\hline site code & utmx & utmy & Quad \\
\hline gm1a & 482000 & 5004250 & Lin. Mnt. \\
\hline gm1b & 492800 & 4975900 & Divide Lake \\
\hline gm1c & 493500 & 4983800 & Big Horn Peak \\
\hline gmld & 478200 & 4988300 & Lin. Mnt. \\
\hline gmle & 493800 & 4979450 & Divide Lake \\
\hline gmlf & 480600 & 5007740 & Lone Indian \\
\hline gmlg & 498450 & 4977860 & Divide Lake \\
\hline gm1h & 473300 & 4990862 & Lin. Mnt. \\
\hline gmli & 499250 & 4973335 & Divide Lake \\
\hline gm1j & 495650 & 4976627 & Divide Lake \\
\hline gmlk & 496520 & 4985840 & Big Horn Peak \\
\hline gm2a & 474638 & 4991066 & Lin. Mnt. \\
\hline gm $2 b$ & 488200 & 4992350 & Sunshine Point \\
\hline $\operatorname{gm} 2 c$ & 490450 & 4990100 & Big Horn Peak \\
\hline $\operatorname{gm} 2 d$ & 487750 & 4992100 & Sunshine Point \\
\hline $\operatorname{gm} 2 \mathrm{e}$ & 490600 & 4990500 & Sunshine Point \\
\hline $\operatorname{gm} 2 f$ & 487850 & 4991100 & Sunshine Point \\
\hline $\mathrm{gm} 2 \mathrm{~g}$ & 483370 & 5006500 & Lone Indian \\
\hline $\operatorname{gm} 2 \mathrm{~h}$ & 492250 & 4987550 & Big Horn Peak \\
\hline $\operatorname{gm} 2 \mathrm{i}$ & 492650 & 4988760 & Big Horn Peak \\
\hline $\operatorname{gm} 2 \mathrm{j}$ & 493675 & 4980375 & Divide Lake \\
\hline gm2k & 499870 & 4973320 & Divide Lake \\
\hline $\operatorname{gm} 3 a$ & 481550 & 5007800 & Lone Indian \\
\hline gm3b & 483450 & 5004700 & Lone Indian \\
\hline $\operatorname{gm} 3 c$ & 483980 & 5005620 & Lone Indian \\
\hline $\operatorname{gm} 3 d$ & 483680 & 5006250 & Big Horn Peak \\
\hline gm3e & 488000 & 4990800 & Sunshine Point \\
\hline gm3f & 482600 & 5006950 & Lone Indian \\
\hline gm3g & 482700 & 5004550 & Lone Indian \\
\hline gm $3 h$ & 491865 & 4990130 & Big Horn Peak \\
\hline $\operatorname{gm} 3 i$ & 493875 & 4983990 & Sunshine Point \\
\hline gm $3 j$ & 472400 & 4990340 & Lin. Mnt. \\
\hline gm3k & 478300 & 4986850 & Lin. Mnt. \\
\hline gm4a & 483100 & 5004900 & Lone Indian \\
\hline gm4b & 484500 & 5006800 & Lone Indian \\
\hline gm4c & 487900 & 4992800 & Sunshine Point \\
\hline gm4d & 488650 & 4992120 & Sunshine Point \\
\hline gm4e & 492100 & 4975700 & Big Horn Peak \\
\hline gm4f & 483440 & 5005600 & Lone Indian \\
\hline $\mathrm{gm} 4 \mathrm{~g}$ & 491900 & 4990630 & Big Horn Peak \\
\hline gm4h & 492200 & 4988240 & Big Horn Peak \\
\hline gm4i & 489615 & 4991500 & Sunshine Point \\
\hline gm4j & 471610 & 4989480 & Lin. Mnt. \\
\hline gm4k & 477050 & 4987350 & Lin. Mnt. \\
\hline
\end{tabular}




\begin{tabular}{|c|c|c|c|}
\hline gm5a & 493400 & 4976070 & Divide Lake \\
\hline gm5b & 481250 & 5007850 & Lone Indian \\
\hline $\operatorname{gm} 5 \mathrm{c}$ & 477770 & 4987630 & Lin. Mnt. \\
\hline $\operatorname{gm} 5 \mathrm{~d}$ & 487400 & 4989350 & Sunshine Point \\
\hline gm5e & 487350 & 4990800 & Sunshine Point \\
\hline gm5f & 487250 & 4990125 & Sunshine Point \\
\hline gm5g. & 483140 & 5006050 & Lone Indian \\
\hline gm5h & 493820 & 4978950 & Divide Lake \\
\hline gm5i & 484623 & 4989630 & Sunshine Point \\
\hline $\operatorname{gm} 5 \mathrm{j}$ & 496375 & 4977590 & Divide Lake \\
\hline gm5k & 497750 & 4977620 & Divide Lake \\
\hline gm51 & 489250 & 4991950 & Big Horn Peak \\
\hline gm6a & 481950 & 5007650 & Lone Indian \\
\hline gm6b & 478750 & 4989300 & Lin. Mnt. \\
\hline gm6c & 489600 & 4988150 & Big Horn Peak \\
\hline gm6d & 487500 & 4991300 & Sunshine Point \\
\hline gm6e & 481250 & 5008500 & Big Horn Peak \\
\hline gm6f & 482740 & 5005000 & Lone Indian \\
\hline gm6g & 494600 & 4978070 & Lone Indian \\
\hline gm6h & 495300 & 4977870 & Divide Lake \\
\hline gm6i & 496110 & 4974620 & Divide Lake \\
\hline gm6j & 497870 & 4973750 & Divide Lake \\
\hline gm6k & 481100 & 5009000 & Lone Indian \\
\hline tmla & 533500 & 4859300 & Two Ocean \\
\hline tmlaa & 542640 & 4861450 & Whetstone \\
\hline $\operatorname{tm} 1 b$ & 533700 & 4858600 & Two Ocean \\
\hline $\operatorname{tm} 1 b b$ & 539180 & 4861800 & Two Ocean \\
\hline $\operatorname{tm} 1 \mathrm{c}$ & 534800 & 4859800 & Two Ocean \\
\hline tm1cc & 530950 & 4860550 & Two Ocean \\
\hline tmld & 540300 & 4859200 & Whetstone \\
\hline tmle & 532600 & 4857500 & Moran \\
\hline $\operatorname{tmlf}$ & 542625 & 4860050 & Whetstone \\
\hline tmlg & 542550 & 4861250 & Whetstone \\
\hline $\mathrm{tm} 1 \mathrm{~h}$ & 523500 & 4834500 & Moose \\
\hline $\mathrm{tm} 1 \mathrm{i}$ & 530250 & 4860300 & Two Ocean \\
\hline $\operatorname{tm} 1 j$ & 532620 & 4861800 & Two Ocean \\
\hline $\operatorname{tm} 1 \mathrm{k}$ & 537700 & 4856050 & Moran \\
\hline $\operatorname{tm} 11$ & 535300 & 4851050 & Moran \\
\hline $\operatorname{tm} 1 \mathrm{~m}$ & 532920 & 4856580 & Moran \\
\hline $\operatorname{tm} 2 \mathrm{a}$ & 533752 & 4857323 & Moran \\
\hline $\operatorname{tm} 2 a a$ & 528200 & 4869050 & Colter Bay \\
\hline $\operatorname{tm} 2 b$ & 533770 & 4856838 & Moran \\
\hline $\operatorname{tm} 2 \mathrm{bb}$ & 536750 & 4856670 & Moran \\
\hline $\operatorname{tm} 2 c$ & 540000 & 4859000 & Two Ocean \\
\hline $\operatorname{tm} 2 d$ & 534900 & 4858600 & Two Ocean \\
\hline $\operatorname{tm} 2 e$ & 530385 & 4860168 & Two Ocean \\
\hline $\operatorname{tm} 2 f$ & 535000 & 4856730 & Moran \\
\hline $\operatorname{tm} 2 g$ & 520830 & 4832368 & Moose \\
\hline $\operatorname{tm} 2 \mathrm{~h}$ & 521568 & 4833481 & Moose \\
\hline
\end{tabular}




\begin{tabular}{|c|c|c|c|}
\hline $\operatorname{tm} 2 \mathrm{i}$ & 520580 & 4832880 & Moose \\
\hline $\operatorname{tm} 2 j$ & 533998 & 4856607 & Moran \\
\hline $\operatorname{tm} 2 k$ & 529380 & 4835800 & Moose \\
\hline $\operatorname{tm} 3 a$ & 536900 & 4862750 & Two Ocean \\
\hline $\operatorname{tm} 3 a a$ & 541920 & 4858400 & Whetstone \\
\hline $\operatorname{tm} 3 b$ & 540100 & 4859700 & Two Ocean \\
\hline $\operatorname{tm} 3 b b$ & 541400 & 4854740 & Davis Hill \\
\hline $\operatorname{tm} 3 c$ & 538750 & 4856400 & Moran \\
\hline $\operatorname{tm} 3 \mathrm{cc}$ & 538490 & 4860050 & Two Ocean \\
\hline $\operatorname{tm} 3 d$ & 532900 & 4838000 & Shadow Mtn. \\
\hline $\operatorname{tm} 3 \mathrm{e}$ & 533500 & 4839200 & Shadow Mtn. \\
\hline $\operatorname{tm} 3 f$ & 529100 & 4864870 & Colter Bay \\
\hline $\operatorname{tm} 3 g$ & 533892 & 4854809 & Moran \\
\hline $\operatorname{tm} 3 \mathrm{~h}$ & 521450 & 4834398 & Moran \\
\hline $\operatorname{tm} 3 \mathrm{i}$ & 521070 & 4833500 & Moose \\
\hline $\operatorname{tm} 3 j$ & 534200 & 4863500 & Two Ocean \\
\hline $\operatorname{tm} 3 \mathrm{k}$ & 539700 & 4855130 & Moran \\
\hline $\operatorname{tm} 31$ & 538400 & 4856300 & Moran \\
\hline $\operatorname{tm} 3 m$ & 540420 & 4858070 & Shadow Mtn. \\
\hline $\operatorname{tm} 5 \mathrm{a}$ & 537900 & 4856300 & Moran \\
\hline $\operatorname{tm} 5 \mathrm{aa}$ & 527300 & 4840550 & Moose \\
\hline $\operatorname{tm} 5 \mathrm{~b}$ & 548353 & 4855055 & Davis Hill \\
\hline $\operatorname{tm} 5 \mathrm{bb}$ & 526551 & 4838505 & Moose \\
\hline $\operatorname{tm} 5 \mathrm{c}$ & 549300 & 4855400 & Davis Hill \\
\hline $\operatorname{tm} 5 \mathrm{~d}$ & 528750 & 4835450 & Moose \\
\hline $\mathrm{tm} 5 \mathrm{e}$ & 530300 & 4837300 & Moose \\
\hline $\operatorname{tm} 5 \mathrm{f}$ & 542470 & 4858550 & Whetstone \\
\hline $\operatorname{tm} 5 \mathrm{~g}$ & 529450 & 4866650 & Colter Bay \\
\hline $\mathrm{tm} 5 \mathrm{~h}$ & 532375 & 4841720 & Shadow Mtn. \\
\hline $\operatorname{tm} 5 \mathrm{i}$ & 530360 & 4863200 & Two Ocean \\
\hline $\operatorname{tm} 5 \mathrm{j}$ & 530425 & 4864425 & Two Ocean \\
\hline $\operatorname{tm} 5 \mathrm{k}$ & 526551 & 4838250 & Moose \\
\hline $\operatorname{tm} 51$ & 530749 & 4839475 & Shadow Mtn. \\
\hline $\operatorname{tm} 5 \mathrm{~m}$ & 526260 & 4834370 & Moose \\
\hline $\operatorname{tm} 6 a$ & 541000 & 4858400 & Whetstone \\
\hline $\operatorname{tm} 6 a a$ & 525125 & 4848640 & Jenny Lake \\
\hline $\operatorname{tm} 6 b$ & 532750 & 4851500 & Moran \\
\hline $\operatorname{tm} 6 \mathrm{bb}$ & 534100 & 4862850 & Two Ocean \\
\hline $\operatorname{tm} 6 c$ & 522750 & 4842750 & Moose \\
\hline $\operatorname{tm} 6 \mathrm{cc}$ & 524100 & 4838250 & Moose \\
\hline $\operatorname{tm} 6 d$ & 522300 & 4841500 & Moose \\
\hline tm6e & 522800 & 4838200 & Moose \\
\hline tm6f & 542520 & 4862125 & Whetstone \\
\hline tm6g & 530450 & 4861400 & Two Ocean \\
\hline $\operatorname{tm} 6 \mathrm{~h}$ & 531700 & 4851700 & Moran \\
\hline $\operatorname{tm} 6 \mathrm{i}$ & 527200 & 4838300 & Moose \\
\hline $\operatorname{tm} 6 j$ & 538400 & 4855500 & Moran \\
\hline tm6k & 531379 & 4843250 & Shadow Mtn. \\
\hline $\operatorname{tm} 61$ & 529290 & 4837625 & Moose \\
\hline
\end{tabular}

